\title{
Tackling the multi-actor and multi-level complexity of European governance of knowledge policies: transnational actors in focus
}

\author{
Tatiana Fumasoli, UCL Institute of Education, UK \\ Bjørn Stensaker, University of Oslo, Norway \\ Martina Vukasovic, Ghent University, Belgium
}

\section{Background and relevance}

The construction and on-going integration of the European Higher Education Area (EHEA) and the European Research Area (ERA) have reshaped the European knowledge policies, i.e. the policies related to higher education, research and innovation. The emergence of a European layer beyond the nation state has added further complexity in the governance of knowledge and its multi-level endeavour (Piattoni, 2010). For some, different sets of governance chains across local, regional, national and European level have been set in motion (Moos \& Wubbels, 2014). Others see the creation of a new policy space in education as an example of how the EU constructs multiple arenas to coordinate diversified actors and engage appropriate agencies and elites in relevant policies (Lawn, 2011).

Other scholars have focused on the tensions emerged with the addition of a European layer in higher education, research and innovation. On the one hand, this has led to vertical tensions between actors at different governance levels (e.g. the European Commission creeping competence in the area of higher education, Trondal (2002)). On the other hand, it has also intensified already existing horizontal tensions between actors from different sectors, such as higher education, science and technology or innovation (Chou \& Gornitzka, 2014). Apart from such multi-level and multi-sector challenges to coordination, the increasing involvement of non-state actors at the local, national and European levels has added further complexity to European governance of knowledge policies. Participation and influence of non-state actors in governance reflects what Piattoni calls the state-society dimension (2010), it adds a multi-actor aspect to the multi-level one (Chou, Jungblut, Ravinet, \& Vukasovic, 2017) and a 'transnational flavour' to already existing supranational and intergovernmental dynamics (Elken \& Vukasovic, 2014).

In this context it is thus relevant and urgent to study transnational actors as particular organizational forms emerging and thriving in the European arena (Ball \& Junemann, 2012; Pataki, 2015). To do this it is necessary to analyse such actors highlighting the differences and commonalities in their structures, identities, roles, as well as the links in which they are embedded, and the influence they can exert in the formation of knowledge policies.

Indeed the distinctive power and resources of European transnational actors are related to their geographical, economic, and political proximity to the EU institutions (Lawn \& Lingard, 2002), but, we argue, it is an empirical issue to understand how such power and resources play out in the policy process. Against this backdrop, this special issue aims to map and to investigate relevant transnational actors in European knowledge governance. It does so by presenting five empirical cases - an expert group, two university alliances, three student unions, the academic associations, a national research council - that provide a fine-grained analysis of the complex latticework of collective actors, division of labour, linkages and positions that form the European governance of knowledge. Drawing from these in-depth cases we aim to contribute to the understanding of the mechanisms at work in the making of European knowledge policies. 
The overarching research questions addressed in this special issue are:

1. How can transnational actors in European Higher Education, Research and Innovation, be conceptualized?

2. What role do transnational actors play in European knowledge policy processes?

3. How are they embedded in the European governance structures? How do they connect to other actors and processes in the European knowledge policy arenas? What are the factors empowering and constraining such links?

4. What are the implications of such engagement(s) on governance of knowledge policies and on the structure of the EHEA and ERA?

Each of the five papers in the special issue focuses on a distinctive European transnational actor striving to influence both the processes and outcomes of knowledge policy-making. These include the European Qualifications Framework Advisory Group (EQFAG); the European university Association (EUA) and the League of European Research Universities (LERU); the European Students' Union (ESU), the Erasmus Student Network (ESN) and the European Students' Forum (AEGEE); the European academic associations; and, finally, the Swedish Research Council, a national intermediary agency actively engaged in European research policy making.

All contributions draw upon Europeanization and EU studies, multi-level governance theory, institutional theory and higher education and research policy studies. They also combine a number of relevant theoretical concepts and perspectives including policy networks, advocacy coalitions, interest groups and intermediation, meta-organizations, stakeholder theory, world polity theory and professionalism. Through combining these concepts and perspectives, the aim of the special issue is to shed light on the characteristics, roles, division of labour, involvement, and influence of the transnational actors in the development of the knowledge policies of Europe. Equally, the special issue provides an empirical analysis of the related issues of democratic representation, of mobilized expertise and legitimacy. Finally, through the lens of insider-outsider actors in policy processes, or the centre-periphery dichotomy, the papers provide an illustration of how the Europe of Knowledge is structured with unequal participants and unequally distributed resources (Fumasoli et al 2015).

The contributions comprising the special issue have been presented at various international conferences, including annual meetings of the European Consortium for Political Research (ECPR) and Consortium of Higher Education Researchers (CHER). A dedicated workshop was hosted in May 2016 by ExCID (Expert cultures and institutional dynamics: Studies in higher education and work) a research group at the Department of Education, University of Oslo (Norway) to mainstream the different contributions into a coherent whole.

The following sections elaborate on the notion of transnational actors, provide an overview of the relevant theoretical perspectives and briefly present each paper. As a conclusion, we revisit the overarching research questions formulated above and outline a research agenda.

\section{Transnational actors - what are they, how can we study them and why do they matter?}

For the purposes of this special issue we characterize transnational actors as collective non-state actors whose identities, organizational structures, mandate, scope and embedding go distinctively 
across national borders. Along the same line, European transnational actors can be considered as operating across governance levels, both vertically (e.g. national and European levels) and horizontally (state and non-state) (Piattoni 2010).

Transnational actors in their various forms have thus far been subject to various disciplines and theoretical strands within social sciences, including international relations, comparative politics, policy analysis, organizational sociology and educational research. Their role has also been explored in connection to European integration, in particular with respect to the multi-level governance context and the role of experts. The following provides key concepts and insights from these research strands and relate them to transnational actors in European governance of knowledge policies.

European integration entails the creation of an additional governance layer above the nation state. Decision-making takes place across several governance levels - European, national, regional, local - and involves multiple actors, including various EU institutions, national, regional and local authorities as well as non-state actors (Eising, 2004; Piattoni, 2010). Such a multi-level governance context does not necessarily imply a neat division of jurisdictions; in the case of the EU it can result in various overlaps (Börzel, 2010; Hooghe \& Marks, 2003) and tensions (Chou \& Gornitzka, 2014; Fumasoli, 2015). All contributions to this special issue have embedded their analysis in the context of multi-level governance, focusing on relationships between actors at different governance levels and implications of such relationships on the outcomes of policy processes.

It is necessary to also unpack the multi-actor governance, and this requires considerations of both organizational and political aspects. As the contributions of Vukasovic \& Stensaker and Klemenčič \& Palomares illustrate, operating across governance levels is often coupled with a nested organizational structure, e.g. local or national non-state organizations operating domestically are members of a European association that, in this context, is considered a transnational actor. This nested organizational structure brings forward an important organizational feature - most transnational actors are effectively organizations of other organizations. In other words, transnational actors are predominantly meta-organizations whose basic characteristics membership, decision-making processes, policy positions, as well as the status and strategies visà-vis other actors - are fundamentally different compared to organizations whose members are individuals (Ahrne \& Brunsson, 2008). The implications of this is that there is a complex dynamic which affects core attributes of both the meta-organization and its members, such as their legitimacy and status in their relevant policy arenas, policy agendas, internal organizational structures and processes, as well as strategic positioning towards other state or non-state actors.

Many of the transnational actors that are in the focus of this special issue are actively involved in policy-making at the European level, very often on behalf of their members, as can be read in Vukasovic \& Stensaker on university alliances, Klemencic and Palomares on students' unions, and in Fumasoli \& Seeber on academic associations. As such, they constitute interest groups, an increasingly important channel for articulation of public interest in modern democracies (Richardson, 1995). On the demand side, policy-makers seek interest groups involvement because they can provide valuable policy resources, such as information, expertise and political support (Bouwen, 2002). On the supply side, interest groups are given the mandate by their members and constituents to represent them towards policy-makers at various levels of governance and lobby for their policy preferences (Beyers, Eising, \& Maloney, 2008). In the European context, given the concerns about the EU's democratic deficit (Kohler-Koch \& Rittberger, 2007), the participation of interest groups is seen as a promise of increased EU legitimacy and transparency, and this also goes for European initiatives in higher education such as the Bologna Process (Elken \& Vukasovic, 2014; Yagci, 2014). However, participation of interest groups can also be a pitfall if access to EU 
policy-makers is limited to only a handful of groups and if the groups themselves do not faithfully represent the interests of their members (Binderkrantz, 2009). One of the key characteristics of interest groups is their status in the European policy arena. The literature distinguishes between 'insiders' and 'outsiders'. Insiders are organizations that have been recognized by policy-makers as partners in the policy process and engage in direct lobbying. Outsiders are organizations that do not have access to the relevant policy arena so their lobbying strategy is indirect and relies on public pressure and the use of media (Beyers et al., 2008).

Apart from interest groups, individual experts as well as their intermediary bodies are also involved in European knowledge policies. While reliance on experts has been the hallmark of European governance since the early days of the EU (Gornitzka \& Holst, 2015; Gornitzka \& Sverdrup, 2008, 2011), in particular due to its institutional and issue complexity (Zahariadis, 2013), the increase in knowledge production over time and the focus on knowledge economies has further strengthened the importance of experts in policy-making processes. However, with such growing involvement of experts - providing advice but also taking decisions themselves- come also concerns over legitimacy and effectiveness of these new governance arrangements, and the extent to which knowledge is being politicized (Gornitzka \& Holst, 2015). Such concerns point to the questions about who participates as an expert in policy processes concerning knowledge, what institutional arrangements supporting their participation and what are implications for policy outcomes thereof. In this special issue, Elken's and Persson's contributions each focus on different aspects of expert involvement, including modes of participation, institutionalization of European level expert groups and the role national intermediary bodies play in developing long-term financial and institutional commitments, such as the European Research Council.

Weaving these different perspectives, this special issue contributes to the on-going debate, in the European Educational Research Journal and elsewhere, on the shifting relationship between governance and knowledge, and how new actors and processes influence the shaping and content of policy within the field of education (Delvaux \& Mangez, 2008). The individual articles are particularly focusing on how transnational actors position themselves in the more networked forms of governance that have emerged in Europe during the recent decades. While much research suggests that European policy processes within education are driving national policies of standardization through various forms of evaluative and measurement techniques (Brady \& Bates, 2015; Ozga, 2012; Ozga, Dahler-Larsen, Segerholm, \& Simola, 2011), the contributions in this issue focus on how transnational actors are trying to influence the formation of policies, and how their involvement implies nuancing the standardization thesis.

\section{Overview of individual articles}

The European Qualifications Framework Advisory Group (EQFAG) is analysed by Mari Elken, who sheds light on the conditions allowing for the achievement of organizational stability and the building of legitimacy as a key actor in the European arena. Elken's study shows that, while the EU constructs policy spaces to be filled up, actors profit of room to manoeuver and flexibility as of how to take on their new role. Within an institutionalist perspective, the decrypting of the institutionalization process points to European arenas (also) as opportunity structures for policy entrepreneurs and highlight the vibrant dynamics at play in the European governance of knowledge.

Martina Vukasovic and Bjørn Stensaker compare two university alliances - EUA and LERU highlighting how diverse membership bases (i.e. comprehensive vs. selective) and diverse 
resources lead to somewhat differentiated roles and representation of interests in European policymaking. While both have rather easy access to EU decision-makers, their legitimacy has different basis, affecting their positioning as well as the breadth and ambiguity of interests they advocate for. This contribution offers a fine-grained analysis of actors, linkages, and processes at play in the European arena.

Looking at three European student organizations (ESU, ESN, AEGEE) Manja Klemencic and Fernando Miguel Galan Palomares investigate the conditions determining insiders and outsiders in European knowledge policy processes. Their paper shows how legitimacy play a major role in accessing EU institutions and policy processes, even when organizational structures and resources are similar. These findings are particularly relevant in shedding light on how the EU grapple with and filters the complexity of multi-level and multi-actor environments, selecting actors deemed as legitimate.

Tatiana Fumasoli and Marco Seeber provide a mapping of the European academic associations, focusing on their missions, their structures and their positioning. Their findings articulate a nuanced landscape where traditional scholarly associations coexist with socially orientated academic associations. Equally, their paper offers an insight on the different patterns of centre-periphery structures from a geographical, political and resource perspective. The quantitative analysis points to the coexistence of traditional and innovative academic organizations with highly varied levels of access to European institutions.

Finally, Bo Persson investigates the Swedish research council and its active engagement in European policy-making, in the specific case of the construction of the European Research council. The paper shows how national actors can occupy distinctive spaces in the European policy arenas and leverage on their organizational capacity and legitimacy to contribute to agenda setting and policy formation. Importantly, the paper shows how national actors are able to do this bypassing their own state authorities and become a part of a European policy arena.

All papers show that engaging in the European governance of knowledge is on the one hand conditioned by the policy space in that policy processes defined by the EU are often clearly demarcated and differentiated. On the other side, we can observe policy processes that are more open as to their structuring and are characterised by a less clear role demarcation. The articles demonstrate that multilevel governance takes different forms, and that these policy processes can be both emergent and/or steered through design (Hooge \& Marks 2003).

\section{Towards a research agenda on European transnational actors in knowledge policies}

The in-depth analyses provided in the special issue show that European transnational actors can be conceptualized and compared according to their mandates and missions, organizational structures and decision-making processes, through their linkages to the EU institutions, the levels and types of influence in policy making, and their position in the broader arena of European knowledge policies. These characteristics can be seen as the outcome of policy design, of strategic intent, but also of incremental and organic changes. Along this line, transnational actors transform themselves over time and depending on changing constellations of actors, processes and outcomes around them.

The papers have also pointed to the importance of expertise, legitimacy and representation. This leads to the characterization of the European governance of knowledge as an evolving, dynamic space where not only constraints but also opportunities are present. In this respect the special 
issue contributes significantly to the scholarly debate on new organizational forms, new governance actors and arrangements in the European space of educational policy (Ball 2009(Pataki, 2015).

Another key finding of this special issue is the variety of roles actors play in this governance space. As underlined by other studies on European knowledge policies, different actors provide expertise and legitimacy to the policy processes (Chou \& Gornitzka, 2014). This is illustrated by Elken on the EQFAG, by Vukasovic and Stensaker in their analysis of alliances and university associations, by Klemencic and Palomares on students' unions, and by Fumasoli and Seeber in their study of European academic associations. While these actors do not have monopoly on expertise, they do have characteristics that enable them to be seen as legitimate players at European level. Their legitimacy also paves the way for another role often undertaken by the actors studied, that of the agenda-setters, in which they can find opportunity to articulate their interests also at European level (Richardson, 1995).

However, our special issue not only confirms earlier findings but expands them by identifying other roles taken on by the actors involved in European governance of knowledge. One such role is related to the top-down arrangements that sometimes characterize the European policy space, and is related to how policy decisions are followed up and turned into implementation processes in which both professional and civic actors take part. This role is noted by Vukasovic and Stensaker, and by Klemencic and Palomares in their study where university and student associations respectively are provided with economic resources to carry out political decisions at European level. Equally, Elken shows that the European policy space can develop in a more organic way, where emergent actors (like the EQFAG) are increasingly entrusted a key role in policy implementation. Our special issue, specifically the contribution by Persson, also identifies a bottom-up process in which a national actor takes an active role in shaping European policy and institutions, bypassing its own national authorities.

Yet another role detected among the new inhabitants of the European policy space is that of being a recruitment arena for the new policy professionals. This is particularly visible in how students' associations produce policy talent that may later transfer to other policy actors. This role should not be underestimated as it provides a mechanism for diffusion of European scripts and for sustaining the European policy space in the long run. Hence, we show that transnational actors undertake multiple roles that are quite closely interrelated, and that the acquired expertise and legitimacy engender new roles and opportunities in the European arena. Whether all of these expanded roles always contribute to 'repair' the democratic deficit in Europe is perhaps more questionable (cf. Kohler-Koch \& Rittberger, 2007).

The multiple roles identified also suggest that the linkages between various policy actors can acquire different forms, and that it is possible to identify some factors empowering and constraining such links. One important factor is organizational capacity: we have seen how several European transnational actors are meta-organizations, which may find difficult to establish themselves as collective actors (Ahrne \& Brunsson, 2008). An important feature that may enable them to become more integrated is the existence of a professional secretariat capable to engage in the numerous policy events and opportunities at European level, and acting as the node between policy actors. The fact that a number of university associations, student associations, and academic associations have established their own secretariat in Brussels, shows how proximity with EU institutions is pursued, but also points to the possibility that such policy networks may act increasingly autonomously from their membership basis (cf. Klüver \& Saurugger, 2013; Kohler-Koch, 2010). While case studies showcased in this issue have somewhat limited information on how these linkages play out, the various articles nevertheless suggest that such professional secretariats are important enablers in policy processes. 
Policy linkages are also dependent on other factors, such as legitimacy. To be perceived as a legitimate representative of particular interests could be one reason for the establishment of the socalled E4-group - consisting of European Students' Union (ESU), European Association for Quality Assurance in Higher Education (ENQA), European Association of Institutions of Higher Education (EURASHE) and European University Association (EUA). These four transnational actors have developed close mutual links over time as part of the development of the European Higher Education Area. Such close links sometimes result in quite unified policy positions of the four organizations, as demonstrated by the development of the European Standards and Guidelines for quality assurance (see the article Klemencic and Palomares). To bring together experts and various stakeholders in a structured way is, as Elken demonstrates in her study, a powerful way to align actors and create a joint vision in developing policy areas. In order to confirm that this is the outcome of European design aimed to coordinate actors and enhance elite groups (Lawn 2009) further empirical research is warranted.

Turning to the implications of complex transnational actor constellations for the European policy area, we argue that our special issue has shed light on one of the key disputed themes related to European knowledge governance - the issue of complexity versus standardisation. While several studies suggest a correlation between European policy processes and increased standardisation (Brady \& Bates, 2015; Ozga et al., 2011), we contend that the empirical findings offered in this special issue resonate more with those strands of research problematizing such direct relation. Indeed, the policy dynamics in the Europe of Knowledge are complex and far less predictable in their overall implications (as suggested by e.g. Maassen \& Olsen, 2007; Piattoni, 2010). Several articles in the special issue address - directly and indirectly - the issue of standardisation by studying policy content, the framing of policy processes, and the emergence of specific formal structures, suggesting a more nuanced stance. Factors that contribute to this complexity include the number of actors involved, the ways they are involved in the policy process and their capacity to engage in the issues at hand. While expertise and legitimacy could be considered requirements to access and influence policy processes, we contend that organizational structures, resources, identities and decision-making processes of these transnational actors need to be scrutinized further. The latter point suggests that insights from comparative politics and organizational studies might be combined into a valuable framework for European policy studies in general, and that we need more studies in this area if we are to understand the development of the Europe of Knowledge.

\section{References}

Ahrne, G., \& Brunsson, N. (2008). Meta-organizations. Cheltenham: Edward Elgar.

Ball, S. J., \& Junemann, C. (2012). Networks, New Governance and Education. Bristol: Policy Press.

Beyers, J., Eising, R., \& Maloney, W. (2008). Researching Interest Group Politics in Europe and Elsewhere: Much We Study, Little We Know? West European Politics, 31(6), 1103-1128. doi:10.1080/01402380802370443

Binderkrantz, A. S. (2009). Membership Recruitment and Internal Democracy in Interest Groups: Do GroupMembership Relations Vary Between Group Types? West European Politics, 32(3), 657-678. doi:10.1080/01402380902779162

Börzel, T. A. (2010). European Governance: Negotiation and Competition in the Shadow of Hierarchy. JCMS: Journal of Common Market Studies, 48(2), 191-219. doi:10.1111/j.1468-5965.2009.02049.x

Bouwen, P. (2002). Corporate lobbying in the European Union: the logic of access. Journal of European Public Policy, 9(3), 365-390. doi:10.1080/13501760210138796 
Brady, N., \& Bates, A. (2015). The standards paradox: How quality assurance regimes can subvert teaching and learning in higher education. European Educational Research Journal. doi:10.1177/1474904115617484

Chou, M.-H., \& Gornitzka, Å. (2014). Building a European knowledge area: an introduction to the dynamics of policy domains on the rise. In M.-H. Chou \& $\AA$. Gornitzka (Eds.), Building the Knowledge Economy in Europe: New Constellations in European Research and Higher Education Governance (pp. 1-26). Cheltenham: Edward Elgar.

Chou, M.-H., Jungblut, J., Ravinet, P., \& Vukasovic, M. (2017). Higher education governance and policy: an introduction to multi-issue, multi-level and multi-actor dynamics. Policy and Society, 36(1), 1-15. doi:10.1080/14494035.2017.1287999

Delvaux, B., \& Mangez, E. (2008). Towards a sociology of the knowledge-policy relation. Literature review: integrative report on knowledge and policy.

Eising, R. (2004). Multilevel Governance and Business Interests in the European Union. Governance, 17(2), 211-245. doi:10.1111/j.1468-0491.2004.00244.x

Elken, M., \& Vukasovic, M. (2014). Dynamics of voluntary policy coordination: the case of Bologna Process. In M.-H. Chou \& A. Gornitzka (Eds.), The Europe of Knowledge: Comparing Dynamics of Integration in Higher Education and Research Policies (pp. 131-159). Cheltenham: Edward Elgar.

Fumasoli, T. (2015). Multi-level governance in higher education. In J. Huisman, H. de Boer, D. D. Dill, \& M. Souto-Otero (Eds.), The Palgrave International Handbook of Higher Education Policy and Governance (pp. 76-94). Basingstoke: Palgrave Macmillan.

Gornitzka, Å., \& Holst, C. (2015). The Expert-Executive Nexus in the EU: An Introduction. Politics and Governance, 3(1).

Gornitzka, Å., \& Sverdrup, U. (2008). Who are the experts? The informational basis of EU decision-making. Retrieved from Oslo:

Gornitzka, Å., \& Sverdrup, U. (2011). Access of Experts: Information and EU Decision-making. West European Politics, 34(1), 48-70. doi:10.1080/01402382.2011.523544

Hooghe, L., \& Marks, G. (2003). Unraveling the Central State, but How? Types of Multi-level Governance. American Political Science Review, 97(02), 233-243. doi:doi:10.1017.S0003055403000649

Klemenčič, M. (2012). The Changing Conceptions of Student Participation in HE Governance in the EHEA. In A. Curaj, P. Scott, L. Vlasceanu, \& L. Wilson (Eds.), European Higher Education at the Crossroads: Between the Bologna Process and National Reforms (pp. 631-653). Dordrecht: Springer Netherlands.

Klüver, H., \& Saurugger, S. (2013). Opening the black box: The professionalization of interest groups in the European Union. Interest Groups \& Advocacy, 2(2), 185-205. doi:10.1057/iga.2013.2

Kohler-Koch, B. (2010). Civil society and EU democracy: 'astroturf' representation? Journal of European Public Policy, 17(1), 100-116. doi:10.1080/13501760903464986

Kohler-Koch, B., \& Rittberger, B. (2007). Debating the democratic legitimacy of the European Union. Lanham, MD: Rowman and Littlefield.

Lawn, M. (2011). Standardizing the European Education Policy Space. European Educational Research Journal, 10(2), 259-272. doi:10.2304/eerj.2011.10.2.259

Lawn, M., \& Lingard, B. (2002). Constructing a European Policy Space in Educational Governance: The Role of Transnational Policy Actors. European Educational Research Journal, 1(2), 290-307. doi:10.2304/eerj.2002.1.2.6

Maassen, P., \& Olsen, J. P. (Eds.). (2007). University Dynamics and European integration. Dordrecht: Springer.

Moos, L., \& Wubbels, T. (2014). EERA: A Participant or an Agent in European Research Policy? A Governance Perspective. European Educational Research Journal, 13(4), 451-463. doi:doi:10.2304/eerj.2014.13.4.451

Ozga, J. (2012). Governing knowledge: data, inspection and education policy in Europe. Globalisation, Societies and Education, 10(4), 439-455. doi:10.1080/14767724.2012.735148

Ozga, J., Dahler-Larsen, P., Segerholm, C., \& Simola, H. (Eds.). (2011). Fabricating quality in education : data and governance in Europe. London: Routledge. 
Pataki, G. (2015). Novel forms of research governance and their possible impact on the future of educational research. European Educational Research Journal, 14(1), 56-64. doi:doi:10.1177/1474904114566140

Piattoni, S. (2010). The theory of multi-level governance: conceptual, empirical, and normative challenges. Oxford: Oxford University Press.

Richardson, J. J. (1995). The market for political activism: Interest groups as a challenge to political parties. West European Politics, 18(1), 116-139. doi:10.1080/01402389508425060

Trondal, J. (2002). The Europeanisation of Research and Higher Educational Policies: Some Reflections. Scandinavian Political Studies, 25(4), 333-355. doi:10.1111/1467-9477.00075

Yagci, Y. (2014). Setting Policy Agenda for the Social Dimension of the Bologna Process. Higher Education Policy, 27(4), 502-528. doi:doi:10.1057/hep.2013.38

Zahariadis, N. (2013). Building better theoretical frameworks of the European Union's policy process. Journal of European Public Policy, 20(6), 807-816. doi:10.1080/13501763.2013.781815 